Etnográfica

Revista do Centro em Rede de Investigação em

Antropologia

vol. 11 (2) | 2007

Vol. $11(2)$

\title{
The Pauliteiros de Miranda: from local symbol to intangible cultural heritage?
}

Os Pauliteiros de Miranda: de símbolo local a património cultural imaterial?

\section{Barbara Alge}

\section{(2) OpenEdition}

\section{Journals}

Electronic version

URL: https://journals.openedition.org/etnografica/1997

DOI: 10.4000/etnografica.1997

ISSN: 2182-2891

\section{Publisher}

Centro em Rede de Investigação em Antropologia

Printed version

Date of publication: 1 November 2007

Number of pages: 353-369

ISBN: 0873-6561; E-ISBN 2182-2891

ISSN: 0873-6561

\section{Electronic reference}

Barbara Alge, "The Pauliteiros de Miranda: from local symbol to intangible cultural heritage?", Etnográfica [Online], vol. 11 (2) | 2007, Online since 27 September 2012, connection on 10 February 2022. URL: http://journals.openedition.org/etnografica/1997 ; DOI: https://doi.org/10.4000/ etnografica. 1997

\section{(c) (1) (8)}

Etnográfica is licensed under a Creative Commons Attribution-NonCommercial 4.0 International License. 


\title{
The Pauliteiros de Miranda: from local symbol to intangible cultural heritage?
}

\section{Barbara Alge}

\begin{abstract}
This text is on a Portuguese stick dance known as dança dos paulitos. The analysis is based on field research the author carried out in Paris and Portugal between 2003 and 2007. The focus lies here on the stick dancers from the concelho (municipality) of Miranda do Douro situated in North Eastern Portugal, the so called Pauliteiros de Miranda. The evolution from their revival to patrimonialisation processes is discussed and it is shown how the dance contributes to the promotion of a local community and how it is turning into a regional and national symbol. A distinction between the object-oriented and process-oriented type of revival is made by examining the ritual and folkloristic performance contexts.
\end{abstract}

KEYWORDS: stick dance, Miranda, folklorisation, revival, local identity, patrimonialisation.

\section{SCHOLARLY DISCUSSION ON REVIVAL PROCESSES HAS BEEN GOING ON for quite some time (see, for example, Bausinger and Brückner 1969), whereas patrimonialisation of cultural phenomena is a recent issue in anthropology and sociology. ${ }^{1}$ \\ Revival is expressed in different ways such as folklorisation, institutiona- lisation, objectification, commercialisation and mediatisation of culture and has been observed in Europe since the end of the $19^{\text {th }}$ century. In Portugal, ethnomusicology and anthropology use the word "folclorização" to express the process of construction and institutionalisation of folklore, or fixed perfor- mative practices that represent the tradition of a locality, region or nation}


(Castelo-Branco and Freitas Branco 2003: 1). Revitalisation and revival express the idea of safeguarding, or bringing back into use material which is about disappearing and adapt it to a new era and/or a new context. They are always coloured by time and context. In dance tradition, revival is usually mentioned in the context of staged folklore presentations and revival movements (Zebec 2006: 97).

Owe Ronström differs between the object-oriented and process-oriented type of revival in the following way:

the object-oriented type of study often stresses tradition as the handing over of a set repertoire of objectively existing, bounded cultural objects, ceremonies, rituals, customs and habits from "the folk" or the "old peasant society" as a valuable cultural heritage to be protected as an expression of national and cultural identity,

whereas

the process-oriented type of study bases its understanding of tradition on the idea that traditions are not simply objectively existing "out there", but that they are constructed, created or appointed; the relationship between society and its cultural heritage is not natural but symbolic (Ronström 1996: 8).

This text discusses the evolution from revival to patrimonialisation processes of a Portuguese stick dance and shows how the dance contributes to the promotion of a local community, how it enacts local identity and how it is turning into a regional and national symbol. A distinction between the objectoriented and process-oriented type of revival is made by examining the ritual and folkloristic performance contexts.

\section{THE DANCE AND ITS CHARACTERISTICS}

The male ${ }^{2}$ stick dancers from North Eastern Portugal are called "Pauliteiros" - a word that derives from "paulito" (small stick). The stick dance of binary metrum is called dança dos paus, dança dos paulitos, dança dos Pauliteiros and, in Mirandês language, la dança and dança de palotes. It is practised in the district of Bragança (Trás-os-Montes), primarily in the high-plateau of Miranda (concelhos ${ }^{3}$ of Miranda do Douro, Vimioso and Mogadouro).

The dance is characterized by the use of two sticks that the dancers hit to the rhythm of the music played by the gaiteiros, a musical group composed 
by gaita-de-foles (bagpipe), caixa (small drum) and bombo (big drum), or by the so called tamborileiro, i. e. the individual that plays tamboril (drum) and fraita (three-holed pastoral flute) at the same time. It is performed by eight men ${ }^{4}$ in a specific costume, either comprising white embroidered skirts, woollen socks, decorated vests (coletes) and hats, or black trousers, white shirts, black vests and decorated hats. The second costume is nowadays only found in one village, but used to be worn in many, possibly all villages of the region.

In Spain, the homologue dance is called danza de palos or paloteo. Anne Caufriez supposes that the dance might have reached Miranda through the population of the Spanish region of León (Caufriez 1981: 278).

The Pauliteiros have been subject of reflection of historians, priests, ethnographers and foklorists since the end of the $19^{\text {th }}$ century (Viterbo 1892: 274; Padre João Manuel Pessanha 1886, cit. in Deusdado 1898). In the 1930s, the stick dance was studied by Rodney Gallop, whose interpretations were overtaken by dance ethnologists of the time, like, for example, Gertrude Kurath, and members of the English Folk Song and Dance Society (Gallop 1961 [1936]). The author is of the opinion that R. Gallop's writings contributed to the high visibility that the Pauliteiros got amongst Portuguese ritual dances. Most of the works on the Pauliteiros are descriptive or try to interpret the origin and symbolism of the dance. Authors like Ferreira Deusdado (1898), the Abade de Baçal (Alves 1990 [1925]) and José Miranda Lopes (1933: 139) interpret the Pauliteiros as a reminiscence of the pyrrhic dance, a Greek dance fight that was overtaken by Romans. Indications that the dança dos paulitos could be a form of sword dance, are, among others, found in Rodney Gallop (1961 [1936]: 169), Luís Chaves (1942: 158) and Tomaz Ribas (1982: 77). Rodney Gallop sees a ritual origin in the dança dos paulitos and writes:

Spirited and martial as the dança dos paulitos is in character, it is only one link in a long chain of similar dances running through the Peninsula and all round Europe, the origin of which is ritual rather than military (Gallop 1961 [1936]: 171).

In the author's opinion, the dança dos paulitos belongs to the pan-European type of chain sword dances that were especially widespread in Europe in the Middle Ages and were performed by guilds in Corpus Christi processions (see also Corrsin 1997).

The musical repertoire of the dança dos paulitos is composed by laços (in Mirandês "Thaços") and passacalles. "Laço" is the term used in Portugal and

4 Today, there exist already a female stick dance group in the neighbouring district of Mogadouro and in the city of Miranda do Douro.

5 Musical pieces interpreted by gaiteiros in processions. 
Spain for the music associated to the dança dos paulitos and can also be sung or played instrumentally. The author joined around 60 lhaços through oral and written sources, of which some correspond to the repertoire of Spanish danzas de palotes (Matellán 1987; and Alge 2005a). Concerning choreography and content of the lhaços, there can be distinguished between religious, ritual and dramatic lhaços (Alge 2005b: 13-19). For the musical structure of the dance see Alge (2005a).

The dancers are divided into the positions "guias" ("guides") and "peões" ("pedestrian") and distinguished in space by attributes like front, back, inside, outside, left and right.

Each dance is a different composition of the main choreographical figures "quatrada", "corrida", "passagem" and "desvolta" and, in the ritual lhaços, dramatic figures. Each choreographical figure is composed by certain ways or patterns of hitting the sticks and a movement pattern for the feet ${ }^{6}$ (Alge 2006 [2004]: 132). The ritual lhaços Bicha, D. Rodrigo and As Rosas have a different choreography and are danced with castanets instead of sticks.

The Pauliteiros are a ritual dance and differ from other Portuguese dances by being composed by men, ${ }^{7}$ by having an own repertoire called lhaços, by using a particular costume, by using sticks and by its particular choreography.

Pauliteiros are found in a broad area of North Eastern Portugal, but this text focuses on the Pauliteiros from the concelho (municipality) of Miranda do Douro, the so called Pauliteiros de Miranda, including groups from the villages Palaçoulo, Duas Igrejas, Malhadas, Fonte de Aldeia, Cércio, São Martinho de Angueira, Granja, Picote, Constantim, Póvoa, the vila Sendim, the Associação dos Professores do Planalto Mirandês (Association of the Professors from the Mirandese High-Plateau) and the city of Miranda do Douro.

\section{SOCIO-CULTURAL CONTEXT OF THE PAULITEIROS DE MIRANDA}

Miranda is part of the region of Trás-os-Montes and is a concelho of the district of Bragança that boarders to Spain and lays at the river Douro in the Mirandese high-plateau and the Terra Fria, a geographical area which is characterised by very cold winters and very hot summers. ${ }^{8}$ The concelho is composed by 17 parishes with a population of around 8.000 inhabitants. Capital of the concelho is the city of Miranda do Douro. In nearly all villages of the concelho, people speak a language different from Portuguese, namely the Mirandês, ${ }^{9}$ a dialect of the old

6 Margarida Moura Fernandes calls this pattern "passo de Pauliteiros" (Fernandes 1991: 25).

7 A characteristic that is in a process of change as female groups emerged in the concelho of Mogadouro in the 1980s, in the city of Miranda do Douro in 2006 and in Bemposta (Mogadouro) in 2007.

8 In the region of Trás-os-Montes this climatic specificity is expressed in the proverb "nove meses de Inverno, três de inferno".

9 As well as a further variant, namely the Sendinês of the vila of Sendim. 
Asturo-Leonese that got recognized as co-official language in 1999 (Ferreira and Raposo 1999). A social and cultural unity was maintained between the Terra de Miranda, i.e. Miranda and neighbouring concelhos, and the Spanish regions of Aliste and Sayago (Zamora): a similar dialect, the same songs and melodies, similar musical instruments and the same festive customs, like, for example, the danza de palos (Matellán 1987: 43). Despite this ethnographic unity with Spain, the Mirandeses (people from Miranda) emphasize their community identity by evoking the agro-pastoral communitarian organization that was maintained until the 1930s. Today, relicts of this organization are found in communitarian fountains, communitarian fields and communitarian festivities.

Socio-economic change of the region happened due to the construction of the dams over the river Douro in the 1950s, the industrialisation of agriculture, the retornados, i.e. Portuguese that returned from the colonial war in African countries in the 1970s, as well as emigration and migratory exodus of the population especially from the 1960s on.

Countries chosen for emigration are primarily France, Germany, Canada and Brazil.

Young Mirandese people are obliged to work or study in big Portuguese cities or abroad. This is one of the reasons for the Pauliteiros' difficulty to set up a dance. In the village of Constantim, for example, many boys work as guards for the Guarda Nacional Republicana (GNR). Reasons for emigration are, in the author's opinion, lack of communication possibilities due to the isolated situation of Trás-os-Montes, missing scholarly institutions, unemployment and a high rate of analphabetism among the older population.

However, today, the University of Trás-os-Montes and Alto Douro, the recently constructed Casa da Cultura and Casa da Música in Miranda do Douro, cultural associations like bagpipe associations or the donkey association and eco-touristic activities, as well as the Internet, are factors of the socio-economic development of the region. The effects of the Internet are seen in the increasing number of Websites and Blogs that promote the region and the communication among its inhabitants (see, for example, www.bragançanet.com, www.nuobas.blogspot.com or http://agarramestespalos.blogspot.com).

\section{FIELD WORK}

The study on the Pauliteiros de Miranda is based mainly on field work carried out by the author in Paris and Portugal between 2003 and 2007. In June 2003, the author made the first interview for her research with Domingos Aires, leader of a Pauliteiros group from Saint-Denis (Paris). In the concelho of Miranda do Douro, the author has stayed for 10 days in August 2003, for two 
months between October 2003 and January 2004, as well as - posterior to her master's thesis - for each time one week in August, September and December 2004, for some days in May, September and October 2005 and for another week in December 2005. In Lisbon, near Porto and on the island of Madeira the author recorded another four presentations of Pauliteiros de Miranda.

For audio-visual recording, the author used a digital handy-cam, a DAT recorder, ORTF-microphones and an analogue and digital photo camera. The recordings are archived in the Phonogram Archive in Vienna (Austria).

\section{THE PERFORMANCE CONTEXTS OF THE PAULITEIROS DE MIRANDA}

The author makes a distinction between the stick dancers performing as a ritual in local religious festivities, the "dançadores" or "community dancing", and the institutionalized stick dancers performing outside this context, the "Pauliteiros" or "rancho dos Pauliteiros".

However, as will be shown later, the dançadores as well as the Pauliteiros were revived or revitalized. Thus, the ritual context manifests the objectoriented type of revival and the folkloristic context the process-oriented type of revival.

\section{Dança dos paulitos as ritual: the dançadores}

Rituals are special, prominent, liminal junctures of customs in the life cycle, occasions at which the expression of identity is particularly emphasized. These are occasions during which the awareness of community is strengthened and common experience with a particular sense and symbolic meaning is actualized. The feeling of the integration and unity of the community is realized (Cohen 1985: 50, cit in Zebec 2006: 100).

The Pauliteiros de Miranda dance in local religious festivities of their home locality and are sometimes contracted to dance in religious festivities of other localities as well. This is what the author calls the "ritual context of the dança dos paulitos".

At the beginning of the $20^{\text {th }}$ century, nearly every village of Miranda used to have its "own" dançadores that danced in honour of a local Saint. However, due to emigration and migration, there are today not always enough members to form a dance. Although various functions of the dançadores in the religious festivities in Miranda will be referred to, it is important to mention that practices differ between the groups.

In the following part, the functions of the stick dancers in the ritual context will be described. It is important to mention that not all of these elements are always executed in a festivity. Moreover, it is a model of a religious festivity 
based on the author's observation and on written sources (Mourinho 1957; 1984; and Neto 1907).

According to António Maria Mourinho (1984: 454), the dançadores are chosen by the mordomos (organizers of religious feasts) and the ensaiador (dance instructor) or the musicians. The rehearsals start around 15 to 20 days before the festive day on the street or in the house of a mordomo where the troupe shares communal meals. The last rehearsal takes place in the centre of the village in front of the local population. In São Martinho de Angueira, the author could still be present at the communal meal ${ }^{10}$ on the evening before the festive day, and in São Martinho and Constantim the last rehearsal took place publicly in the centre of the village.

On the festive day, the gaiteiros wake the village playing the alvorada, a special musical piece that is played while marching through the village early in the morning. The author was still present at the alvorada in all religious festivities.

After the alvorada, the stick dancers dance in front of the houses in order to collect donations for the festivity (peditório). The lhaços can be chosen by the house owners. The offerings for the peditório used to be agricultural products, especially wheat, but due to diminishing agricultural activity in the region of Miranda, it is today mostly money. If a house is in mourning, the Pauliteiros pray and take off their hats. Around the donation of an alqueire de trigo (a measure of wheat), they dance one of the ritual lhaços with castanets. Some Pauliteiros still respect the custom of dancing the religious lhaço Senhor Mio in front of the church at the beginning of the peditorio and during the collection, in front of other holy places. In the peditório, the Pauliteiros do not wear the Pauliteiros' costume apart from hats and vests. Because of the length of a peditório, the dances are usually shortened. The "community dancing" element of the Pauliteiros is expressed in the peditórios when ex-dançadores join the dance spontaneously. Only in the village of Constantim, the author still watched the lhaço Senhor Mio danced during the mass, more precisely at the moment of the holy bread's elevation. In São Martinho, the Pauliteiros enter the church at the beginning of the mass playing castanets. In the processions, Pauliteiros accompany the statues of the Saints by playing castanets or by carrying the statues, while the gaiteiros play passacalles.

At the end of the religious part of the festivity, the Pauliteiros dance in front of the church in the most perfect way, i.e. in complete costume, well ordered and - if possible - the whole repertoire.

According to António Mourinho (1957: 153), the Pauliteiros ask strangers for donations during dinner and according to José Maria Neto (1907: 40), they dance once more after dinner in the centre of the village. However, the author could not verify these elements any more. 


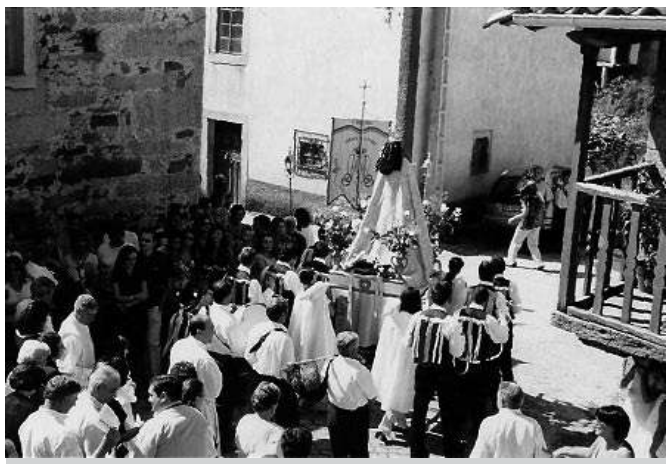

Figure 1

Pauliteiros de São Martinho in the trouser costume accompany the statue of Our Lady playing castanets, followed by the gaiteiros, feast in honour of Our Lady of Rosário, São Martinho de Angueira, 22.8.2004. (photo: author)
The religious festivities of Miranda take place during the summer festivity cycle (Solstício do Verão) in honour of Our Lady of Rosário and Holy Barbara and in the winter festivity cycle (Solstício do Inverno, between Christmas and Epiphany) in honour of St. John the Evangelist and St. Stephen. Until the beginning of the $20^{\text {th }}$ century, the dança dos Pauliteiros was also danced in the Corpus Christi festivity (Neto 1907: 37). In Constantim, on St. Stephen's day, the stick dancers are accompanied by ritual figures during the peditorio and the dancing in front of the church.

\section{The dança dos paulitos in folkloristic contexts: the Pauliteiros}

Since 1892 or probably before, ${ }^{11}$ Pauliteiros also dance outside their ritual context (Viterbo 1892: 274). Today, they perform in festivals, feiras (messes) and profane festivities in Miranda, in other Portuguese regions and abroad. Groups of Pauliteiros are founded in Portuguese cultural associations like, for example, tunas, ${ }^{12}$ and in Portuguese emigrants' communities in France, Germany, Canada, Brazil and Argentina (Cravo 2000: 94; and Mourinho 1984: 161). ${ }^{13}$

Since 2003, the author observes an increasing interest in the Pauliteiros by the younger population from Miranda. However, it is more interested in the "institutionalised" ${ }^{14}$ Pauliteiros - what the author calls the rancho dos Pauliteiros ${ }^{15}$ - than dancing in the ritual context. Reasons for this interest are various: A stick dancer from Póvoa (ca. 25 years) informed the author that the dancers were primarily motivated by travel opportunities, convivial experiences and extra money (DAT 3/4). According to Célio Pires (30 years), bagpiper from

11 Photos of the performance of the Pauliteiros de Constantim in Lisbon in 1898 can be found in the Arquivo Fotográfico da Câmara Municipal de Lisboa (http://arquivomunicipal.cm-lisboa.pt).

12 Tunas are ensembles of string instruments and are frequent among university students in Portugal.

13 In June 2003, the author did some research among the Pauliteiros of Saint-Denis (Paris).

14 Most of the ranchos dos Pauliteiros are at the same time a cultural association in their home locality.

15 Ranchos folclóricos are institutionalised dance and music groups presenting local traditions outside their original context and emerged in Portugal in the late $19^{\text {th }}$ century (Castelo-Branco and Freitas Branco 2003: 4). 
Constantim, other reasons for motivation are the high esteem that the Pauliteiros get in the region of Miranda and the "importance of maintaining the tradition and roots of Miranda" (DAT 2/11). Before emigration and migration of the local population, such a motivation was not necessary, because there were enough boys to form a dance. In fact, the dança dos paulitos seems to have been a good possibility for the youth to join in a communitarian activity before local associations, football clubs and ranchos of mixed dances were founded. Since 2001, cultural activities for the local youth increased with the creation of music schools in Sendim and Miranda do Douro. In 2004, an official music school opened in the Casa da Música of Miranda do Douro.

One of the first rancho dos Pauliteiros was the Pauliteiros de Constantim when they performed in Lisbon in 1898. In 1934, Rodney Gallop took the Pauliteiros de Cércio to perform in the Royal Albert Hall in London. ${ }^{16}$ From then on, the Pauliteiros de Cércio were promoted by the City Council of Miranda do Douro and served as a model for the folkloristic activity of other Pauliteiros de Miranda. The Pauliteiros de Cércio were somewhat responsible for the objectification of the Pauliteiros by standardising its appearance. Finally, António Maria Mourinho, a priest from the village Duas Igrejas, contributed the most to the promotion of the Pauliteiros through his publications and the institutionalisation of the Pauliteiros in the Grupo Folclórico Mirandês de Duas Igrejas, a mixed dance group. This group presented the Pauliteiros de Miranda internationally and transformed the traditional stick dance by including other instruments like ferrinhos (metal triangles), pandeiros and pandeiretas (species of tambourines).

An impact of the folklorization process on form and repertoire of the dance is also observed today. The Pauliteiros de S. Martinho are, for example, still preserving elements of the ritual context: the requirement of not being married, the use of trousers in the religious festivity in São Martinho, ritual meals, accompanying the procession, dancing in the peditório, dancing before and after the mass, executing ritual lhaços around the wheat, etc. However, in folkloristic contexts they change their form by using the skirts costume, by dancing ritual lhaços around sticks and other objects and by using sticks in the ritual lhaço Bicha. Fortunato Preto (53 years), leader of the Pauliteiros de S. Martinho, explains the last fact in the following way: "La Bicha é, no fundo, um lhaço sem paus, mas por causa da perda de interesse dos espectadores, os Pauliteiros de São Martinho introduziram-nos." ${ }^{17}$ (CC MdD2/A/2). Ana Pires (ca. 80 years) and Isabel Meirinhos (ca. 70 years) from S. Martinho were surprised when the

16 In England, the folk movement started reviving morris and sword dances in the 20th century (Buckland 1991: 1).

17 "La Bicha is actually a lhaço without sticks, but because of the loss of interest of the audience, the Pauliteiros de São Martinho introduced them.” (translated by Barbara Alge) 
author told them about the skirts costume the Pauliteiros use outside the village and exclaimed: "Já não são os Pauliteiros de S. Martinho!"18 (CC S.M. I/A/2, 23.8.2003).

Elements of the dance that are only observed in folkloristic contexts are the Capa de Honras, ${ }^{19}$ the carrier of the group's flag, the individual that replaces the sticks, verbal presentation of the group and the repertoire, as well as a more spectacular repertoire. Lhaços that are used as "spectacular repertoire" are primarily the Oficios, in which the Pauliteiros imitate professions, the Salto ao Castelo, where the dancers build a human tower and one dancer jumps over the tower, and the lhaço $O 25$ that is also known as the "lhaço para partir os paus" ("the lhaço to break the sticks"). The folkloristic context affects the repertoire of the Pauliteiros as well: a group knows today a maximum of 25 lhaços, but due to time restriction in festivals, it often does not dance more than 5 to 10 lhaços. As folkloristic activity increases, this affects the variation of the repertoire in the ritual context as well and results in uniformation of the repertoire of different groups. About the impact that folklorization has on the texts of the lhaços, the author has written elsewhere (Alge 2005b: 20).

The folk music group Galandum Galundaina, which includes the Pauliteiros de Fonte de Aldeia in their spectacle, has a big impact on the image of the Pauliteiros de Miranda. Other groups of Pauliteiros start imitating the group by adding some of their most popular musical pieces into their own spectacle (see, for example, the Pauliteiros de Malhadas, DV 69/1).

Although the meaning of the Pauliteiros in the ritual context is to serve for the local Saint and to express a rite de passage and a fertility rite, in the folkloristic context, the Pauliteiros present themselves like "superstars" and make new arrangements of the dance: a "striptease" part, i.e. the taking off of the vests in the lhaço Salto ao Castelo, in the case of the Pauliteiros de Fonte de Aldeia (DV 48), hitting the sticks until they break in the case of the Pauliteiros de Malhadas (DV 68), and new choreography of the lhaço Bicha and a singing part in the lhaço Canedo in the case of the Pauliteiros de Miranda do Douro (DV 53). Such variations in the dance serve as elements for the group identity and serve in the competition with other Pauliteiros groups.

Other competitive elements are in the case of the Pauliteiros de S. Martinho the claim of being "the only authentic Pauliteiros" by still respecting the "tradition of the Pauliteiros". In fact, the case of S. Martinho seems more to be a "retraditionalization" (Boissevain 1992: 7) or a "reinvention of tradition" (Hobsbawm and Ranger 1983) - especially taking into account that this group, like most of the Pauliteiros, was revived.

18 “These are no more the Pauliteiros de São Martinho!" (translated by Barbara Alge)

19 A man wearing a brown wool coat previously used as a raincoat by shepherds (pastores) and still today given to honoured visitors in Miranda. 


\section{REVIVAL}

Through conversations with members of different Pauliteiros de Miranda, the author tried to reconstruct the history of each group. However, this was impossible due to the definition of an "active" and "inactive group": some Pauliteiros still dance in local religious festivities, but not in folkloristic contexts, some perform exclusively in folkloristic contexts and some neither dance in one nor the other context, but are still able to establish a group and execute the dance ${ }^{20}$ Besides, the exact moment of a group's dissolution is difficult to determine. Reasons for dissolutions are missing bagpipers or dancers due to emigration and migratory exodus.

The longest period of Pauliteiros' dissolution - as related by Francisco Jesus Fernandes (77 years) - seems to have been around 40 years in the case of the Pauliteiros de Fonte de Aldeia that did not exist between the 1950s and the 1990s (DAT 4/4).

Through conversations with the local population and members of the respective Pauliteiros group, the author realized that most of the groups were revived in the late 1970s. Actually, this date nearly coincidences with what Jeremy Boissevain observed:

[...] after declining for two decades, public celebrations in Europe (and North America) have been increasing since, roughly speaking, the early 1970s. Manning suggests that the florescence is somehow related to modernity and, in particular, to the growth of leisure and consumption in contemporary societies (Boissevain 1992: 1).

The Pauliteiros de Cércio seem to have been the only group existing continuously due to their revitalization by Rodney Gallop in the 1930s and by António Maria Mourinho in the 1940s. In the 1950s, António Mourinho revived the Pauliteiros de Duas Igrejas.

The Pauliteiros de Póvoa were revived after a dissolution of 20 years and started their "folkloristic" activity in 1989. Since 1996, this activity diminished however, due to the death of the bagpiper (DAT 3/9).

The revival is primarily undertaken by ex-dancers, musicians and emigrants. Today, revitalization is motivated by the promotion of the groups through the City Council of Miranda do Douro.

In 2003, there were 10 "official" groups of Pauliteiros de Miranda promoted by the City Council of Miranda do Douro: from Palaçoulo, Sendim, Duas Igrejas, Malhadas, Fonte de Aldeia, Cércio, São Martinho de Angueira, Granja, 
Picote and the Associação dos Professores do Planalto Mirandês. However, also the Pauliteiros de Constantim were still active and the Pauliteiros de Póvoa were still able to set up a dance. The most available groups were the Pauliteiros from Palaçoulo, Sendim, Malhadas and Cércio. As the author saw herself or got to know through conversations with the population - the Pauliteiros de Constantim, Vila Chã, Prado Gatão and Póvoa still danced in the ritual context. In 1993, the City Council of Miranda do Douro founded the "Grupo de Pauliteiros de Miranda do Douro" with members from the City Council, but later this group was dissolved and is today represented by the Pauliteiros of the Associação dos Professores do Planalto Mirandês with teachers from different villages.

In September 2005, Paulo Meirinhos, director of the recently established local music school in Miranda do Douro, who is at the same time member of Galandum Galundaina, founded Pauliteiros in the city of Miranda do Douro. ${ }^{21}$ In 2006, a female stick dancer group, the Pauliteiras, and more recently a children group, the Pauliteiricos, were founded in Miranda do Douro as well. Children groups are also included in the Pauliteiros' associations in Sendim, Palaçoulo and Malhadas.

Among the "official" groups, there is a hierarchy that does not rely upon the quality of music and dance, but upon the group's availability for performances.

\section{THE PAULITEIROS DE MIRANDA AS LOCAL, REGIONAL AND NATIONAL SYMBOL}

The concept of folklorism departs from a positive valorisation of tradition and an aesthetic, commercial or ideological intentionality concerning its use by adapting it to the taste and need of a primarily urban public (Martí I Pérez 1996: 19-20). In the following part, the folklorism in the Pauliteiros de Miranda is shown through the ideological intention of enacting a regional identity, as well as through commercialisation, mediatisation and touristification processes. The Pauliteiros de Miranda are reconstructed ${ }^{22}$ in such a way that they now represent a local, regional and even national symbol.

\section{Regional symbol}

The region of Miranda got visible in Portugal because of the Mirandês. Since 2003, the author observes an increase in the popularity of the Mirandês as a result of promotion by local speakers. The Pauliteiros de Miranda also play an important role in the dissemination of the Mirandês: dances have Mirandese

21 Pauliteiros in the ritual context have never existed in the city of Miranda do Douro.

22 Under "reconstruction of tradition" the author understands a symbolically invented past adapted to the needs of the present. 
titles, examples of the language are presented in folkloristic performances and Galandum Galundaina sing and have published their whole CD-booklet in this language (Galandum Galundaina 2005).

The Mirandês and the Pauliteiros are alongside with the burros mirandeses, a special breed of Mirandese donkeys, and the posta mirandesa, a typical plate from Miranda, symbols of the Mirandese community that emphasizes its sense of close knit community, its "archaic" way of living, its traditional feasts, its religiosity, etc. Yet, new technologies like television and Internet have also reached Miranda and - as it was mentioned before - people no longer live exclusively from agriculture. Theresa Buckland writes that:

On the surface, continuity and expansion in the re-enactment of traditional dance forms may signal evidence of cultural stability. Yet, as Cohen has noted (1985: 91-92), continuity in the outward manifestation of public customary activities may disguise widespread economic and social changes within a given society (Buckland 1991: 53).

The different Pauliteiros groups are today homogenized to represent THE dance from Miranda: they all wear the skirt costume and use their "spectacular repertoire", which will be discussed later, in folkloristic performances. Some groups add extra Mirandese elements to the dança dos paulitos when they perform in a folkloristic context, as, for example, the already referred Capa de Honras. According to Handler and Linnekin (1984: 280), the invention of tradition is selective, i.e. only certain items are chosen to represent traditional national culture. Pauliteiros as a symbol for the city of Miranda do Douro and the region of Miranda are also commercialised in the form of dolls and postcards in tourist shops in Miranda do Douro and Pauliteiros' sticks and parts of their costume can be bought in local artisan shops (see photo next page).

In addition, photographs of Pauliteiros and bagpipes are affixed to the walls of local Mirandese restaurants. Pauliteiros are also used in the strategy of touristification by performing in nearly all eco-touristic and cultural activities of Miranda (see e.g. http://www.cm-mdouro.pt/publicacoes/publicacoes_noticias_detalhe.asp?pub=9606).

\section{Local symbol}

The Pauliteiros do not just select certain elements for the representation of Miranda, but also for their own group's or village's identity. Although, when seen for the first time, the various Pauliteiros de Miranda seem identical, they differ between each other in choice of repertoire and in the interpretation of the dança dos paulitos.

In the choreography of the various Pauliteiros de Miranda there are differences concerning the number of repetitions of the dance (voltas), clashing the 
sticks and the composition of the main choreographic parts. That is why each village used to have its own bagpiper for its group of Pauliteiros. Apart from these differences, there are interesting competitive choreographic elements that help creating a group's identity: the Pauliteiros de São Martinho add for example an extra jump at the end of the dance, they are the only group that uses a special choreographic part called Sete Paus and dance the ritual lhaço Bicha in folkloristic performances - as it was mentioned before - with sticks instead of castanets to maintain audience interest. In their claim of being more "authentic" than other Pauliteiros, they emphasize at the same time the image of the zona raiana (border zone in Northern Miranda) "to be more isolated and to better maintain the traditions". The Pauliteiros de Malhadas express the power and virility of the Pauliteiros by clashing the sticks in an aggressive way, by opening the legs wider than other groups and by never using castanets. An interesting fact is that the population from Malhadas is commonly known as being aggressive in festivities, i.e. that fights between individuals emerge soon. The Pauliteiros de Cércio, on the other hand, refuse to clash the sticks aggressively.



Figure 2 - Porcelain figures representing Pauliteiros in a tourist shop, Miranda do Douro, 8.9.2005. (Photo: author) 


\section{National symbol}

Since 2003, the presence of the stick dance from North Eastern Portugal is increasing in Portuguese media and whole Portugal: In 2004, Pauliteiros were chosen to represent Portuguese culture in the European football championship Euro04. On the 21 th of January 2005, a group of Pauliteiros danced in a "festival of skirts" in a discothèque in Lisbon and on the $4^{\text {th }}$ of September 2005, the Pauliteiros de Fonte de Aldeia danced on stage in the Festa do Avante, one of the most popular Portuguese feasts organised by the Portuguese Communist Party. In October 2006, the author saw a sketch in a Portuguese TV comedy show called "Gato Fedorento" where Pauliteiros and "their special language" were made ridiculous. Pauliteiros are also part of the show of Galandum Galundaina and the Pauliteiros de Malhadas accompanied shows of the Portuguese singer Né Ladeiras. One of the dancers from Malhadas, Esmeraldino Fernandes, member of the Pauliteiros de Malhadas, remembers that Né Ladeiras reconstructed on stage a rustic scenery imitating the region of Trás-os-Montes and that the Pauliteiros group earned around "200 contos" (1000 euros) for their performance of 40 minutes (DV 70/3). Pauliteiros courses are today also offered in regional and national dance festivals.

\section{CONCLUSION}

The dança dos Pauliteiros becomes increasingly visible among other Portuguese music styles and is used as a local, regional and national symbol. The revival and revitalization of the Pauliteiros de Miranda especially from the 1970s on happened in an object-oriented and in a process-oriented way. The objectoriented revival aimed to "maintain the tradition" of the Pauliteiros' dancing in local religious festivities in Miranda, whereas, in the process-oriented revival, the Pauliteiros adapt to modern performance contexts such as festivals and to mediatisation, touristification and commercialisation. The folkloristic contexts and promotion through the City Council of Miranda do Douro provoke standardisation of the appearance of the different Pauliteiros groups. However, for competition among each other, the different groups vary slightly in the realisation of the stick dance.

Patrimony or cultural heritage is defined as "cultural processes" and authenticity serves as criteria in its selection (Bortolotto 2006: 1, 3). The Pauliteiros stick dance is valorised because of its strong connection with the region of Miranda and its patrimonialisation must be seen in the process of socio-cultural change happening in Miranda. The Pauliteiros fulfil on one side the criteria to become intangible cultural heritage of Portugal and, on the other side, fulfil the criteria of a "cultural capital" (Bourdieu 1979) by being distinct from other Portuguese dance groups, by belonging to a rural society and by being connected to the past through their ritual performance context. 


\section{REFERENCES}

ALGE, Barbara, 2006, Continuidade e Mudança na Tradição dos Pauliteiros de Miranda (Trás-os-Montes, Portugal), master's thesis extended and translated from the original German version of 2004, University of Vienna, Faculty for Human and Cultural Sciences.

—, 2005a, "Os lhaços dos Pauliteiros", Revista Brigantia, 35 (3/4), Bragança, pp. 209-224.

—_, 2005b, Os Pauliteiros de Miranda e os "Lhaços": entre a Literatura Popular, a Dança e a Música, série “à mão de respigar”, IELT. Lisbon, Apenas Livros Lda.

ALVES, Padre Francisco Manuel (Abade de Baçal), 1990 [1925], Memórias Arqueológico-Históricas do Distrito de Bragança, vols. IX, X, XI, Palaçoulo, s. n.

BAUSINGER, Hermann, and Wolfgang Brückner (eds.), 1969, Kontinuität? Geschichtlichkeit und Dauer als Volkskundliches Problem. Berlin, Erich Schmidt Verlag.

BOISSEVAIN, Jeremy (ed.), 1992, Revitalizing European Rituals. London, Routledge.

BOURDIEU, Pierre, 1979, La Distinction: Critique Sociale du Jugement. Paris, Editions de Minuit.

BUCKLAND, Theresa Jill, 1991, "Institutions and ideology in the dissemination of Morris dances in the Northwest of England”, Yearbook for Traditional Music, 23, pp. 53-68.

CASTElo-BrANCO, Salwa El-Shawan, and Jorge Freitas Branco (eds.), 2003, Vozes do Povo. A Folclorização em Portugal. Oeiras, Celta Editora.

CAUfriez, Anne, 1981, La Pérennité du romanceiro dans la musique paysanne du Trás-os-Montes (Portugal). Les romances dans l'histoire, leur fonction sociale et leur expression musicale d'aujourd'hui, Dissertation, Ecole des Hautes Etudes en Sciences Sociales Paris.

CHAVES, Luís, 1942, Páginas Folclóricas. Porto, Portucalense Editora.

CORRSIN, Stephen D., 1997, Sword Dancing in Europe: A History. Hisarlik Press.

CRAVO, António, 2000, Os Pauliteiros de Salselas. Salselas, Museu Rural de Salselas.

DEUSDADO, Ferreira, 1898, “A dança de paulitos", Diário de Notícias, 19 de Maio de 1898, Lisboa.

FERNANDES, Margarida Moura, 1991, A Estrutura Rítmica na Dança Popular Portuguesa.

Ensaio de Descrição e Hierarquização segundo Critérios de Acentuação e Duração, master's thesis, Technical University of Lisbon, Faculty for Human Motricity.

FERreIRA, Manuela Barros, and Domingos Raposo, 1999, Convenção Ortográfica da Língua Mirandesa, Câmara Municipal de Miranda do Douro/Centro de Linguística da Universidade de Lisboa.

GAllOP, Rodney, 1961 [1936], Portugal: a Book of Folk-Ways. Cambridge, Cambridge University Press.

HANDLER, Richard and Jocelyn Linnekin, 1984, “Tradition, genuine or spurious”, Journal of American Foklore, 97, pp. 273-290.

HOBSBAWM, Eric, and Terence Ranger, 1983, The Invention of Tradition. Cambridge, Cambridge University Press.

LOPES, José Manuel Miranda, 1933, “Da minha terra. Subsídio para a etnografia de Trazos-Montes. Danças, bailes e folguedos populares”, Revista Lusitana, 31, pp. 138-163, Porto, Livraria Portuense.

MARTí I PÉREZ, Josep, 1996, El Folklorismo. Uso y Abuso de la Tradición. Barcelona, Ronsel.

MATELLÁN, José Manuel González, 1987, "Os laços na dança dos paus - uma literatura popular que une a terra de Miranda e a província de Zamora", Actas das 1. ${ }^{\text {as }}$ Jornadas de Língua e Cultura Mirandesa. Miranda do Douro, pp. 43-54.

MOURINHO, António Maria, 1984, Cancioneiro Tradicional e Danças Populares Mirandesas, Bragança, s.n. 
MOURINHO, António Maria, 1957, “A dança dos paulitos”, Ocidente, 53, Lisbon, pp. 153-164. NETO, José Maria, 1907, Rabiscos. Bragança, Tipografia Ferreira Soeiro.

RIBAS, Tomaz, 1982, Danças Populares Portuguesas. Lisboa, Instituto de Cultura e Língua Portuguesa. RONSTRÖM, Owe, 1996, "Revival reconsidered", World of Music, 38 (3), pp. 5-20.

VITERBO, Sousa, 1892, Artes e Artistas em Portugal: Contribuições para a História das Artes e Industrias Portuguezas. Lisboa, Livraria Ferreira.

ZEBEC, Trvtko, 2006, "The Kolijani ritual event on the Island of Krk, Croatia: continuity or revival?”, Yearbook for Traditional Music, 38, pp. 97-107.

\section{Discography}

Galandum Galundaina, 2005, Modas i anzonas, Emiliano Toste.

LODDO, Daniel, 1995, Mirandun, Mirandela, Chants et Musiques du Concelho de Miranda do Douro (Trás-os-Montes, Portugal), GEMP/La Talvera.

\section{Recordings from the author's fieldwork:}

[The original tapes are archived in the Phonogram Archive of the Austrian Academy of Sciences in Vienna.]

DAT 2/1 1, Célio Pires, 30.10.2003, Constantim.

DAT 3/4, Pauliteiro from Póvoa, 14.12.2003, Póvoa.

DAT 3/9, José dos Ramos Lucas, 14.12.2003, Póvoa.

DAT 4/4, Francisco Jesus Fernandes, 21.12. 2003, Fonte de Aldeia.

DV 7/2, Francisco Preto, 2.11.2003, São Martinho de Angueira.

DV 48, Festa do Avante, 4.9.2005, Seixal.

DV 53, Pauliteiros de Miranda do Douro, 23.12.2005, Miranda do Douro.

DV 68 and 69/1, Pauliteiros de Malhadas 29.6.2006, Ribeira Brava (Madeira).

DV 70/3, Pauliteiros de Malhadas, 2.7.2006, Madeira.

CC MdD2/A/2, Fortunato Preto, 17.8.2003, Miranda do Douro.

CC S.M.1/A/2, Ana Pires and Isabel Meirinhos, 23.8.2003, São Martinho.

\section{Websites}

BORTOLOTTO, Chiara, 2006, “La patrimonialisation de l'immatériel selon l'UNESCO”, résumé de la communication présentée le 16 juin 2006, à la réunion des conseillers à l'ethnologie et des ethnologues régionaux, mission à l'ethnologie (Dapa, Ministère de la Culture), in http://www.lahic.cnrs.fr/IMG/pdf/Bortolotto_juin_06.pdf (acessed 13-2-2007).

Os Pauliteiros de Miranda: de símbolo local a património cultural imaterial? - Barbara Alge Bolseira DOC da Academia das Ciências da Áustria • balge@gmx.at

Este texto fala da dança de paus portuguesa conhecida como dança dos paulitos. A análise baseia-se em pesquisas de campo levadas a cabo pela autora em Paris e Portugal entre 2003 e 2007. Aqui, o foco está na dança dos paulitos do concelho de Miranda do Douro situado no Nordeste de Portugal, os chamados Pauliteiros de Miranda. Discute-se como a dança evoluiu de revivificação a processos de patrimonialização e mostra-se como a dança contribuiu para a promoção duma comunidade local e como se tornou num símbolo regional e nacional. É distinguido entre o tipo de revivificação orientado para o objecto e o tipo de revivificação orientado para o processo em que os contextos performativos rituais e folclorísticos da dança são examinados.

PALAVRAS-CHAVE: dança de paus, Miranda, revivificação, folclorização, identidade local, patrimonialização. 